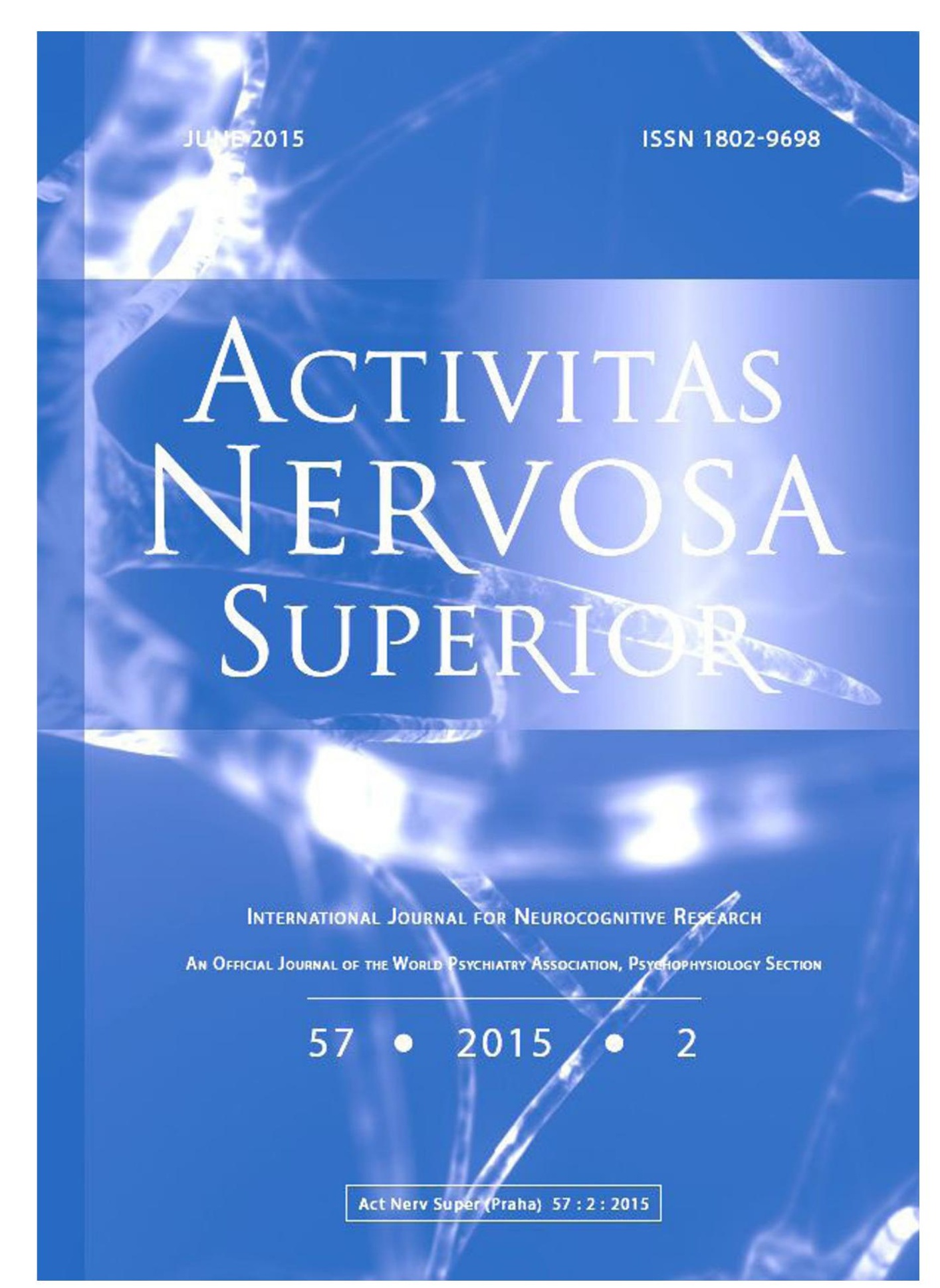

\title{
NEUROSCIENCE IMPLICATIONS OF USING HyPNOANALysis: TwO CASE STUDIES
}

\author{
Jeanne Clark* \\ Aurora University, Aurora, Illinois, USA
}

\begin{abstract}
Neuroscience is providing growing evidence that psychopathology is related to neural integration and amygdala-based implicit memories. Understanding the brain provides psychotherapists a guide for treatment, and neuroscience points to hypnosis as a potent treatment tool. Hypnosis affects functional areas of the brain, including the amygdaloid memory system and neural integration. Hypnosis in itself is not curative. Neuroscience, more recent psychotherapy models, and modern understandings of hypnoanalysis appear to confirm Freud's early observations of hypnosis effectiveness and, for his objection that hypnosis works well for some clients but not for others, explain why. Neuroscience's understanding of the development of psychopathology and psychotherapy models give us tools and models Freud did not have. Using age regression (abreaction) in hypnosis in the context of psychotherapy appear to provide direct access to amygdala-based implicit memories during which the content of implicit memories can be explored for the unconscious meaning and for the responses conditioned during traumatic events. With the skilled use of psychotherapy treatment models while a client is in hypnosis, new patterns can be created through neurologically vividly experiences. These vivid experiences create new, reconditioned patterns that appear to reflect direct changes in the amygdala-based implicit memories and neural integration, evidenced by clients' new, automatic responses in previously difficult circumstances. Two case studies illustrate the use of Ego Psychology, Self Psychology, Attachment and Narrative psychotherapy models during hypnotic age regressions to disconnect stimulus-response patterns in a phobia client and provide vivid experiences of attachment and guidance for a borderline client.
\end{abstract}

Key words: Hypnosis; Hypnoanalysis; Age regression; Implicit memory; Phobia; Borderline personality disorder

\section{INTRODUCTION}

Psychopathology can be theoretically organized from an understanding of the brain in order to devise an approach to treating the problem that is most likely to improve a client's or patient's functioning (Moore \& Tasso, 2012, p.717; Yapko, 2010, p.555). In the context of neuropsychology of mental illness this article reviews some basic psychotherapeutic implications of brain development and the effects of trauma on the brain, especially neuroscience findings indicating that psychological problems may be understood as imbalance in neural integration and conditioning in the amygdala mediated memory system

*Correspondence to: Jeanne Clark,e-mail:dreamswork45@yahoo.com

Received March 19, 2015; accepted May 11, 2015; Act Nerv Super 57(1), 49-58; ISSN-1802-9698 
(Cozolino, 2010, p.34). The author locates the discussion historically addressing Freud's early understanding of hypnosis and refuting his reasons for abandoning the use of hypnosis, using neuroscience to demonstrate why using hypnosis in psychotherapy appears to be effective. Two case studies are presented to illustrate the catalyzing effect of hypnosis on the psychotherapeutic concepts found in Self Psychology, Attachment, Narrative, and Ego Psychology, using them in novel ways to directly edit the beliefs, processes, and stimulus response in implicit memories and to affect functional responses with a phobia and a borderline personality disorder client.

\section{NEUROSCIENCE RELEVANT TO PSYCHOTHERAPY}

Recent findings indicate the crucial role stressful and traumatic memories play in human development. Those memories are mainly consolidated in the amygdaloid memory system, and are the cause of many mental disorders (Cozolino, 2010, p.9). The amygdala memory system represents the implicit memory system. The hippocampal system develops into the explicit memory system. The amygdaloid and hippocampal systems serve different functions as the brain continues to develop. The amygdala system is mainly subconscious, emotional and focused on behavioral patterns, whereas the hippocampal system is organized by language and focuses on visual images, narrative, and the conscious organization of experience (Cozolino, 2010, p.78; LeDoux, 1996).

Recent research findings indicate that during highly traumatic experiences the amygdala's response overwhelms the hippocampus. The traumatic sensory information forms into highly stable, slow-to-degrade implicit memory, dissociated from working memory or conscious cognition (LeDoux, 2003, p.124) and from other ways the brain has for processing information (Freyd, 1998, pp.99-101). These memories have the ability to overwhelm conscious thought processing because the human brain has stronger neural connections from the emotional systems up to the cortex than the rational systems have down to the amygdala (LeDoux, 1996, p.19). Because of plasticity, implicit memories can be changed and the capacity to think more clearly can be developed, all of which has the effect of changing the brain (Cozolino, 2010, pp.336-338).

Recent neuroscience findings are showing increasingly that hypnosis, in many cases, may be a highly effective tool. However the field of hypnosis has not yet capitalized on this information (Vermetten \& Bremner, 2004, p.281; Clark, 2014; Franklin, 1837; Gauld, 1992). Freud was attracted to hypnosis by the work of Charcot (Gauld, 1992, p.306) and, with Breuer, used hypnosis early in his practice for the treatment of hysteria (Nash \& Barnier, 2012. p.208).

In Freud's early work Studies on Hysteria, written in 1895, he recognized that pathogenic memories were the cause of hysterical symptoms. While memories of normal events were consciously available, these traumatic memories were not, or were available only in a summary form without powerful affect. These memories, some decades old, would return with "hallucinatory clarity" with all their "affective coloring" and with the "full force" of recent memories when under the influence of hypnosis. Release of the "strangulated affect" through speech and restoration to conscious memory or removal by suggestion was thought to be curative (Freud, 2010).

Near the end of Freud's writings we find this statement: "Hypnotic influence seemed to be an excellent instrument for our purposes. . . . No substitute for hypnosis has yet been found" (Freud, 2010). Also, recent findings indicate that in many cases hypnosis allows clients to heal rapidly using their own innate resources, without the difficult side effects of medication and other modalities (Barabasz \& Watkins, 2005).

Following this historical context, neuroscience is offering us mounting proof that the effects Freud achieved using hypnosis are real and related to measurable brain activities (Barnier \& McConkey, 2003; Faymonville et al., 2003; Kelliher, 2005). Research indicates hypnosis may significantly influence brain structures that need quieting and those that need enhancing 
(Halsband, Mueller, Hinterberger, \& Strickner, 2009). Brain structures involved in implicit memory, including the amygdala and thalamus and also other structures, such as somatosensory, visual, and auditory cortexes, may be influenced by hypnosis (Barnier \& McConkey, 2003; Faymonville et al., 2003; Hoeft, Gabrieli, Whitfield-Gabrieli, et al., 2012; Müller, Bacht, Prochnow, Schramm, \& Seitz, 2013; Vanhaudenhuyse, Laureys, \& Faymonville, 2014). For example, the amygdala is highly associated with the processing and conditioning of fear, mating, eating and drinking and aggression (LeDoux, 2007). Some data also suggest that hypnosis may influence cerebral functional connectivity (Faymonville et al., 2003).

Functions typically linked to neural connectivity on the level of implicit memory are stimulus response and procedural information we automatically access and act on without conscious thought or decision. These are conditioned responses about which Raz commented in an interview discussing his research (Raz, Fan, \& Posner, 2005). Using hypnosis, Raz said we can ". . . 'un-ring' Pavlov's bell. This seems to be a top-down effect that may be able to override a whole range of impulses" (Kelliher, 2005). In this context certain data may help explain how traumatic stimulus-response memories can be processed and reconsolidated, which may be closely linked to specific changes in brain complexity (Bob et al., 2006, 2009; Bob, 2007) and in this process the new associations replace the fearful ones (Siegel, 2006).

\section{USING HYPNOSIS IN PSYCHOTHERAPY}

Hypnosis can affect somatosensory, visual and auditory cortices, the amygdala, left and right hemispheres, and the prefrontal cortex (Barabasz \& Barabasz, 2012; Bentall, 2000; Hoeft F et al., 2012; Moore \& Tasso, 2012; Müller et al., 2013), which does not mean that hypnosis by itself is curative (Yapko, 2010). The effect is highly dependent on the nature of suggestions given and the experiences that are created (Tasso \& Perez, 2012). Various descriptions of hypnotic and hypnoanalytic treatment methods are available (Brown \& Fromm, 1986; Steven J. Lynn, Rhue, \& Kirsch, 2010; Nash \& Barnier, 2012; Scott, Sr., 1996; Watkins, 1992). One of the most important predictors of a psychotherapy outcome is a positive therapeutic relationship (Cozolino, 2010, p.336). The experience of hypnosis promotes many of the most important aspects of therapeutic relationships--warmth, trust, comfort, security--and lowers defenses with the therapist (Barber, 2012), which indicates that hypnosis can be used in a variety of ways in psychotherapy (Barabasz \& Watkins, 2005; Bryant, 2012; Covino \& Pinnell, 2010; Elkins \& Perfect, 2008; Steven Jay Lynn, Kirsch, Barabasz, Cardena, \& Patterson, 2000; Nash, 2012; Peebles, 2012; Scott, Lagges, LaClave, Nash, \& Barnier, 2012). The specific approach taken within the hypnoanalytic framework is based on historic origins of symptoms that are rooted in implicit memory of traumas that occurred before the symptom appeared (A. Freud, 1951, p, 487; Scott, Sr., 1996).

\section{CASE STUDIES}

\subsection{Case study of phobia}

M., a 34-year-old Caucasian male, came to therapy because of an intense phobia regarding injury. He reported during intake that he was a construction worker; minor injuries were not unusual in his job. He was avoiding a favorite hobby, camping, and was starting to avoid work because his phobia was getting worse.

He had his first major panic attack while watching a first aid video in the Army Reserves. He reported being cut with a pocketknife at Boy Scout camp when he was 8 . He reported that he received a cut on his head at birth. He was also born with an arm deformity that required that he be in a brace for the first year of his life. He reported supportive, healthy relationships with both parents. He was in a relationship of two years and planning to marry. 
The first 45-minute hypnosis session was designed to create an experience of deep, soothing relaxation, the purpose of which was to create a positive association with the office and with me as the therapist, and to strengthen the therapeutic relationship begun during intake. The session included standard imagery invoking peace, calm, and tranquil relaxation; positive suggestions about his worth; protective suggestions to ensure he only used hypnosis when it was safe to do so; and instruction in self-hypnosis. I used voice modulation to develop his sense of safety and relaxation.

During the next two standard hypnoanalytic diagnostic sessions it became evident that M. had a deep, unconscious fear of death and that even hearing about someone else's banging his thumb with a hammer triggered this deep fear. He claimed that while consciously that he was not afraid of death, the joint understanding of this formulation of the problem increased his hope for recovery.

The first age regression session began with guided relaxation and then suggestions for him to go to the scene that first conditioned his mind to develop the problem. He spontaneously went into an age regression to birth. He described the experience step by step and said suddenly that his head hurt. He felt fear and said his mother was also afraid. I asked what he was afraid of and he said he felt he was going to die. He also said he felt alone because his mother seemed preoccupied with her own fear and problems with the delivery. He expressed feeling acutely uncomfortable emotionally with the feeling of being alone. I then guided him to go back even further in time in the pregnancy to when he felt safe. He went back further to an earlier time in the pregnancy. Then I asked him for a memory of when he felt loved and safe. He said he felt loved by a dog when he was a boy. I instructed him to give the love he felt a color. I told him he was surrounded and filled with love and safety and intensified this experience, telling him he was surrounded and filled with the color of love and safety. When he reported that the new experience was vivid, I had him progress back to birth. I emphasized that he was still surrounded and filled with love and safety. He went through the whole experience and said, I feel fine. I'm safe. When he came out of hypnosis, he said, I'm so surprised! I felt a sting on my head where I was cut when I was born. He lifted his hand and touched a place on the top of his head.

At the next session, two weeks later, he reported being presented with the phobic stimulus when a co-worker was cut. He said, I sat there and thought, What's the matter with me? I'm fine! The phobic response was completely eliminated. He reported that he still felt afraid of being afraid, but the phobia was gone.

In subsequent sessions we did additional age regressions to other memories of injury. A consistent factor was the feeling of being alone, even though he was with people who cared about him. We did additional sessions of hypnotic desensitization. I instructed him to vividly recall recent experiences in which he had the phobic response. We made this scene very vivid. Then I instructed him to go to a time before the scene and after the scene when he felt safe. Then, using an imaginary remote control, I had him fast forward and fast reverse through the scene, repeatedly bringing the feeling of safety with him. We continued to do this until he felt completely comfortable with the memory. By the end of fifteen sessions, he reported no feelings of fear or anxiety associated with injury.

This was the first client with a phobia that I treated using hypnoanalysis. I was amazed by this result, a personal reaction that continues after more than a decade of using this process, and one I am not alone in experiencing (Barabasz \& Watkins, 2005). This case illustrates the power of hypnosis to instantly relieve the emotional power of implicit memories. In the age regression described above, we used a Narrative process to discover the unfolding of events and their deeper meaning to him. While his subconscious mind was afraid to die, the deeper fear was of being alone. While he was reliving this preverbal event he experienced it as though it were happening in the present because the amygdaloid memory system lacks a sense of location in time. This is primarily a right-hemisphere experience, but through using hypnosis he was also accessing his left hemisphere, so he could describe the event in words (Cozolino, 2010, pp.274-275). The experience was so vivid that he felt the sensation of a cut on his adult 
head. We created a new meaning for the narrative by reliving the same memory, but with a new sensory experience of feeling loved and safe; therefore he did not die and was, in fact, alive with a new feeling of connection. This restructuring of an implicit memory using my knowledge of narrative and the importance of putting experiences into a sequence of events using words and recreating meaning (Saari, 1991, p.139) had the effect of disconnecting stimulus and response and instantly curing the phobia.

\subsection{Case study of Borderline Personality Disorder}

D., a 40-year-old, low-income Guatemalan-Caucasian female, reported difficult friendships with women toward whom she felt chronically jealous and angry. She reported feeling depressed, lonely, irritable, tired, and wanting to sleep all the time. She said both she and her close friend had put another friend on a pedestal, and they competed for her attention. She felt worse when there was distance in the friendships. While the friendship was going well at the time of intake, she felt sure there would be another crisis. She had strong feelings of being left out, which caused anxiety and difficulty in relationships.

In her childhood history she recounted that when she was six years old, her paternal grandmother, who was her primary caregiver, passed away. Starting around age eight she ran away every weekend to stay with her maternal grandmother. Her father was so abusive when punishing her sister that she had to call police several times to intervene when she was a teenager. This increased her father's anger because of fears of immigration authorities. That fear seemed to prevent immediate new violence. She said her parents were a little careless and put the children in harm's way because of inadequate supervision. Her father was funny in the presence of friends, but with the family he was a very strict Catholic. She constantly tried to impress him. The parents fought and threatened divorce in front of the children; however, financial realities kept them together. Her mother worked full-time at night and was emotionally distant. She said that her mother still hurts her emotionally, promising to do things but never following through. She described putting herself in danger with men and engaging in self-injurious behaviors in her twenties. She was in love with her husband when their relationship started. Now she feels her friendships with women are more important and she is more emotionally involved with them than with her husband.

She has been married since age 19. She reports that this relationship is good. She described herself as having difficulty organizing her schedule and her house. She has difficulty concentrating on tasks and tends to go from one to another, rarely finishing anything. This is a source of conflict with her husband.

\section{Age regressions}

Three hypnotic sessions preceded the first age regression, the same method as described in the first case study. Before the hypnotic part of the first age regression session, I asked D. how she was doing. She reported that she was worried because one friend had asked her to go out to dinner, but it was someone her best friend didn't like. She was worried about losing her best friend if she proceeded. She felt she couldn't tell either of them how she felt because she feels she always has to seem happy so they will like her. This appears to be a situation of disorganized attachment (Applegate \& Shapiro, 2005).

After an induction and instruction to go to a scene from when the problem started, she went to a scene in which she was a baby. She said, I couldn't cry in front of my dad. If he saw a tear, it angered him. I'd have to stop crying. He would just scream. I asked, Where does that leave you? D. replied, By myself. Lonely. I don't think I'm valuable. I'm not important. Emotionally I don't thrive. I need more attention. I want to stay with somebody who gives me attention. I asked, What do you learn about your needs? D. said, They don't get met. I can't be myself. I'm molded to be what Mother wants, to make it easier for her. I suggested that she imagine her adult self comes into the scene knowing just what she needs. What does your adult self do? She picks me up. Holds me. 
Feeds me, loves me. I asked, How does that feel? Warm. I asked her to switch and be her adult self holding her baby self. What new messages do you want to give to your baby self? She wasn't sure. So I asked questions such as How do you feel toward your baby self? She replied, You're valuable. You're important. I want you to be yourself. I'll make sure your needs are met. I love you very much. I'll always be there to take care of you and help you. She began crying and I paused the session to give her a tissue to reinforce the message that it's OK to cry. She continued talking to her younger self: I'll always support you. You're strong, beautiful, and independent. I suggested some additional messages which she immediately said out loud to her baby self. You can cry when you want to cry. I'll talk to you and find out why you're upset. I'll give the best advice I can. I'll always connect to you. I told her to imagine that connection in some form, like a ribbon of light. She nodded that she had done that. I told her, You are connected now. Then she continued: I love you and you're perfect. I told her to be her baby self again being held by her adult self. I told her I was going to repeat these positive messages and I wanted her to hear them as though they were coming from her adult self and that her adult self would absorb them at the same time. I repeated the new messages. I then had her switch back to her adult self. I told her to imagine her heart was full of the light of love and to bring her child self into the light within her heart. I told her that her child self now grows up bringing these new beliefs and feelings with her, integrating fully into her adult self. I asked her how she felt and she replied, Emotionally amazing. Everything you always want to hear. Full. Whole. Complete. Lighter.

After the hypnotic part of the session ended, I again asked how she felt. She replied, Amazing. Then she added, I see myself trying to mold my daughter to make it easier for me. I need to pay attention more to her. I instructed her to use self-hypnosis to imagine taking care of her baby self. Then I asked her how she felt about going to dinner with her friend. She replied, I'm fine. I'm not worried about my friendships.

This first age regression demonstrated an implicit memory in which D.'s parents demonstrated a profound lack of attunement (Applegate \& Shapiro, 2005) and in which she was forced into a situation of reverse mirroring and having to mold herself on a basic physiological level to her parents' needs (Elson, 1988). This implicit memory informed how she expected her friends to relate to her. It forced her to constantly orient herself outwardly, longing for the love and attention she didn't get as a child. Guided by the sound of my voice, which she had already connected with soothing from the earlier preparatory sessions, she was able to manage the anxiety and give a narrative account of what happened and what the implicit meaning was to her. Then she was able to describe very precisely what she needed. We created a vivid, new experience of her receiving exactly what she needed, an experience of precise attunement. She was able to have this experience because the range of emotional experiences available to her was greater while she was in hypnosis. Because hypnosis has the ability to create vivid sensory experiences, she was able to have a vivid, rich sensory experience of being cared for. This provided a powerful holding environment (Goldstein, 2002, p. 99) for her as she experienced this new scene as though it were actually happening neurologically in the present. Hypnosis creates the experience in the somatosensory, visual and auditory cortexes with hallucinatory vividness (Bentall, 2000). While she knew that she was sitting in a chair in my office, her brain was having an experience as though it were real. She had an experience that felt like an actual experience of love. The new, positive experience was absorbed into implicit memory. I repeated those same messages to her so she heard them in her own voice and in my voice. My repeating the positive messages to her added reinforcement to the neural pathways already firing with the experience of love. Her verbal responses indicated it was a very real experience for her. She also now has an image of a loving presence that can always be with her in the image of her adult self. That adult self (ego) has had the experience of being a loving and nurturing presence. On an implicit memory level, this is a completely new, novel experience, so the dopamine systems in the brain trigger rewarding feelings and strengthen the new memory (LeDoux, 1996, p.189). When she is in self-hypnosis at home, D. can recreate this experience for herself and reinforce these new 
neural pathways. As her feelings of neediness and expectation of loss recede, she will be able to use her ego strength more effectively because the amygdaloid memory will be calmer and will be less likely to overwhelm the prefrontal cortex processing system (LeDoux, 1996, p.303). This will strengthen her ego capacities. By using self-hypnosis as a self-soothing tool and to reenact this new experience, the subject uses self-hypnosis as an ego-strengthening tool. In fact, in the process of using self-hypnosis, if D. gets distracted and brings her mind back repeatedly, her prefrontal cortex and other areas associated with concentration will actually grow and become stronger (McGonigal, 2012, p.25) and become less overwhelmed, increasing her ego strength.

Short of physically reenacting such an event, which is considered unethical (NASW, 2008, para.1.10), it is difficult to provide such a direct experience without hypnosis. Additionally, if a psychotherapist were to provide such physical comfort, the therapist would become the object of the client's neediness and reduce the client's self-determination (NASW, 2008, section 1.02). The source of support, care, and love would remain outside the client, and accessible only during therapy sessions.

\section{Second age regression}

Before starting hypnosis, I asked D. how she was doing. She said, I'm PMS'ing like crazy. My thoughts are racing. I'm disorganized. I feel like I'm going crazy. Referring to work, she said, I'm going to make a ton of money selling jewelry. I'm supposed to have a mentor. I feel she's not really teaching me. She's making me feel that I don't want to ask for help. She made a comment; she said, You're doing it but not learning it. After hypnotic induction I suggested she take us to the place where the problem started. She said, I had a track meet. My coach said to get protein so I made myself an egg. I used a dish rag to take it off the stove. It caught fire. It was scary. I asked, What do you do? Get mom out of bed. She starts yelling. She called me stupid. How do you feel when she does that? Insecure. I think, How could I be so stupid? I asked D. to imagine her adult self coming into the scene. I would probably yell at her, too. It was clear to me that she did not have internal models to help her in this situation, so I assisted her in developing a corrective scene. I asked, Did anyone teach you how to use the stove? No. I commented, So young D. is on her own. Yes. I did terrible in that track meet. I asked, What would be more helpful from adult D.? I don't know. I gave her ideas about what might be more helpful, and she said, I explain what happened. I should have taught you. You can't put a dish rag by the burner. She went on to explain how to get an egg of the stove safely. How does young D. feel?

There's guidance. It wasn't my fault. I suggested to her that her younger self ask her adult self for help. Will you help me make my lunch? We then created an extensive scene where her adult self was teaching her younger self and also working alongside her to help her do the tasks of getting ready. She said, I'm learning something new. Then she imagined attending the track meet and cheering for her younger self and her younger self's experiencing that. Near the end I asked, How does that feel? Complete. Taken care of. After the hypnosis ended she said, I yell at my kids too much. Maybe they don't know everything I want.

This second age regression demonstrates a lack of mirroring and the lack of a guiding adult whom D. could admire and emulate, and who would admire her, leaving her vulnerable to narcissistic injury (Elson, 1988, pp.49-51). In talking about her work, D. exhibited grandiosity but not the requisite skill to do the work (Elson, 1988, p.51). At work she was unable to use the input from an adult mentor because she had no inner model of how to learn a skill or how to ask for help. She did not expect her current adult mentor at work to teach her or to admire her, nor could she provide those experiences for her own children. The growth and organization of the brain is deeply influenced by early relationships that stimulate the brain to develop an interactive set of internalized objects just as object relations proposes (Cozolino, 2010, p.41). Her reaction when she said, I would yell at her [her child self], too, demonstrates the power of the implicit memory to determine her current behavior. In this situation, she needed my 
knowledge of Self Psychology and Ego Psychology to help her develop a new scene that created a new internal model.

Her response at the end of the session showed a greater sense of herself when she reported feeling complete. In these age regressions there appears to be a combination of the client's becoming her own self-object, but also using me as the therapist to create a supportive environment, hearing my safe, soothing voice, and responding with exacting imagery to what she felt she needed. During this age regression we helped her develop ego functions. She was demonstrating the capacity for self-reflection, observing her reactions to herself in the scene. The age regression allowed her to develop new skills of thinking about her needs in a more constructive way. It allowed her to have a vivid enactment of developing problem-solving skills. After the hypnotic part of the session, she observed a correlation with her own parenting and made decisions about new ways she could parent her daughter. All of these are ego skills she practiced during the session, giving her a new template from which to work. Additionally, asking her to switch between her child self and her adult self helped her develop a distinction between her primitive needs and her ego capacity. She had an opportunity to practice ego-based skills such as observation, planning, and executing a plan (Goldstein, 1995).

This is not a case that will be cured in a few short hypnosis sessions, because D. grew up with deeply disturbed attachment. The repatterning likely needs to be done at every developmental stage, and along all attachment/nurturance/love and guidance/ structure/discipline vectors. This is a long-term therapy case; however, I do expect it will take much less time than using the same treatment models in talk therapy. Because we can create vivid experiences with highly targeted interventions, it is likely that $\mathrm{D}$. will begin to be able to carry the new sense of self more quickly than if we were not able to directly access and modify the patterns and the emotional arousal and valence in the implicit memories. She has had vivid and immediate positive experiences that give her hope and make coming to therapy highly rewarding for her. When she comes in feeling needy, we can create an experience for her that is immediately emotionally gratifying so that she can begin to look to herself rather than to look with haunting neediness to people who are unlikely to meet the needs she has for mirroring, attunement, attachment, and guidance.

\section{DISCUSSION}

To address Freud's question about why hypnosis works quickly for some clients and more slowly for others, I propose the following: In the case of the phobia, a relatively simple stimulus- response set of neural pathways were the cause of the problem, and so they were easy to change. In someone with more complicated psychopathology, arousal has coordinated learning over a larger set of neurological systems because of parallel plasticity (LeDoux, 2003, pp.303-304). The range of emotional experiences D. had as a child was much narrower and had a direct effect on her sense of self because the ongoing learning in the context of abuse and neglect she developed set personality structures (LeDoux, 2003, p.322) that involve a wider set of neurological systems. Healing will involve disconnecting certain stimulus-response patterns but also building underdeveloped brain capacities through new and broader ranges of affective and cognitive experiences.

Despite the belief expressed by Cozolino that the ability to "'edit and re-edit' emotional memories . . remains on a distant horizon" (2010, p.338), the ability is here today through the theoretically informed use of hypnosis. Because the amygdaloid memory system creates an emotional tone in particular situations, we can tell if the target memories have been resolved by how a client feels in situations that are similar to those that triggered difficult affect, distorted thinking, or problematic behavior in the past. I frequently have clients who come in and say, I feel different, better, and I don't know why. Or, I drive down that road where I used to get anxious and it doesn't bother me. One client had undergone twenty years of psychotherapy. After twenty-two sessions using hypnoanalysis, she said, I don't have anxiety any more. I lived 
with anxiety all my life. She went on to describe very difficult work and family situations. She said, Now, with all of this, I have no anxiety. She looked as though she had experienced a miracle. These new experiences feel automatic, a feature of implicit memory. Nevertheless, further research on the efficacy of using hypnosis in psychotherapy needs to be done to determine these effects and to further uncover the innate abilities of the human brain (Nash, 2012, p.216).

\section{REFERENCES}

Applegate, J. S., \& Shapiro, J. R. (2005). Neurobiology for Clinical Social Work: Theory and Practice (First). New York, NY, US: W. W. Norton and Co.

Barabasz, A., \& Barabasz, M. (2012). Hypnosis and the brain. In The Oxford Handbook of Hypnosis: Theory, Research, and Practice (Paperback, pp. 337-363). Oxford, UK: Oxford University Press.

Barabasz, A., \& Watkins, J. (2005). Hypnotherapeutic Techniques 2E. New York, NY, US: BrunnerRoutledge.

Barber, J. (2012). Reclaiming the cognitive unconscious: integrating hypnotic methods and congitivebehavioral therapy. In The Oxford Handbook of Hypnosis: Theory, Research, and Practice (Paperback, pp. 457-465). New York, NY, US: Oxford University Press.

Barnier, A. J., \& McConkey, K. M. (2003). Hypnosis, human nature, and complexity: Integrating neuroscience approaches into hypnosis research. International Journal of Clinical and Experimental Hypnosis, 51(3), 282-308. http:// doi.org/10.1076/iceh.51.3.282.15524

Bentall, R. (2000). Hypnotic and psychotic hallucinations: Rich data capable of multiple interpretations. Contemporary Hypnosis, 17(1), 21-25. http:// doi.org/10.1002/ch.188

Bob, P. (2007). Hypnotic abreaction releases chaotic patterns of electrodermal activity during dissociation. International Journal of Clinical and Experimental Hypnosis, 55(4), 435-456.

Bob, P., Kukleta, M., Riecansky, I., Susta, M., Kukumberg, P., \& Jagla, F. (2006). Chaotic EEG Patterns During Recall of Stressful Memory Related to Panic Attack. Psysiological Research, 55(1).

Bob, P., Siroka, I., \& Susta, M. (2009). Chaotic Patterns of Autonomic Activity During Hypnotic Recall. International Journal of Neuroscience, 119(2), 240-254. http:// doi.org/10.1080/00207450802325744

Brown, D., \& Fromm, E. (1986). Hypnotherapy and Hypnoanalysis. Hillsdale, New Jersey: Lawrence Erlbaum Associates, Inc., Publishers.

Bryant, R. A. (2012). Hypnosis and anxiety: early interventions. In The Oxford Handbook of Hypnosis: Theory, Research, and Practice (Paperback, pp. 536-547). New York, NY, US.

Clark, LCSW, J. R. (2014, December). A Critical History of Hypnosis" Why The Road Was Less Travelled. Unpublished manuscript.

Covino, N., \& Pinnell, C. (2010). Hypnosis and Medicine. In S. J. Lynn, J. W. Rhue, \& I. Kirsch (Eds.), Handbook of Clinical Hypnosis (2nd ed., pp. 551-573). Washington, CD: American Psychological Association.

Cozolino, L. (2010). The Neuroscience of Psychotherapy: Healing the Social Brain (2nd ed.). New York, NY, US: W. W. Norton \& Company.

Elkins, G., \& Perfect, M. (2008). Hypnosis for health-compromising behaviors. In The Oxford Handbook of Hypnosis: Theory, Research, and Practice (Paperback, pp. 569-592). New York, NY, US: Oxford University Press.

Elson, M. (1988). Self Psychology in Clinical Social Work (1 edition). New York: W. W. Norton \& Company.

Faymonville, M.-E., Roediger, L., Del Fiore, G., Delgueldre, C., Phillips, C., Lamy, M., Laureys, S. (2003). Increased cerebral functional connectivity underlying the antinociceptice effects of hypnosis. Cognitive Brain Research, 17, 225-262.

Franklin, B. (1837). Animal magnetism : report of Dr. Franklin and other commissioners, charged by the King of France with the examination of the animal magnetism as practised at Paris: translated from the French, with an historical outline of the "science", an abstract of the report on magnetic experiments made by a committee of the Royal Academy of Medicine in 1831, and remarks on Col. Stone's pamphlet. Philadelphia: Perkins. Retrieved from http://archive.org/details/56721030R.nlm.nih.gov

Freud, A. (1951). Symposium on genetic psychology: 2. The contribution of psychoanalysis to genetic psychology. American Journal of Orthopsychiatry, 21(3), 476-497. http://doi.org/10.1111/j.19390025.1951.tb00006.x

Freud, S. (2010). Freud: Complete Works. (I. Smith, Ed.) (Digital). Ivan Smith. 
Freyd, J. J. (1998). Betrayal Trauma: The Logic of Forgetting Childhood Abuse (Reprint edition). Cambridge, Mass.; London: Harvard University Press.

Gauld, A. (1992). A history of hypnotism (Vol. xvii). New York, NY, US: Cambridge University Press.

Goldstein, E. G. (1995). Ego psychology and social work practice (2nd ed.). New York: Free Press.

Goldstein, E. G. (2002). Object Relations Theory and Self Psychology in Social Work Practice. New York: The Free Press.

Halsband, U., Mueller, S., Hinterberger, T., \& Strickner, S. (2009). Plasticity changes in the brain in hypnosis and meditation. Contemporary Hypnosis, 26(4), 194-215. http://doi.org/10.1002/ch.386

Hoeft F, Gabrieli JE, Whitfield-Gabrieli S, \& et al. (2012). Functional brain basis of hypnotizability. Archives of General Psychiatry, 69(10), 1064-1072. http:// doi.org/10.1001/archgenpsychiatry.2011.2190

Kelliher, S. (2005). Hypnotic suggestion can reduce conflict in human brain, Weill Cornell medical college researchers report (News Service). New York: Cornell University.

LeDoux, J. (1996). The Emotional brain (1st ed.). New York, NY, US: Touchstone.

LeDoux, J. (2003). Synaptic Self: How Our Brains Become Who We Are. New York: Penguin Books.

LeDoux, J. (2007). The amygdala. Current Biology, 17(20), R868-R874.

Lynn, S. J., Kirsch, I., Barabasz, A., Cardena, E., \& Patterson, D. (2000). Hypnosis as an empirically supported clinical intervention: The state of the evidence and a look to the future. International Journal of Clinical and Experimental Hypnosis, 48(2), 239.

Lynn, S. J., Rhue, J. W., \& Kirsch, I. (2010). Handbook of Clinical Hypnosis (2nd ed.). Washington, DC: American Psychological Association.

McGonigal, K. (2012). The Willpower Instinct. New York, NY, US: Penguin Group.

Moore, M., \& Tasso, A. F. (2012). Clinical hypnosis; the empirical evidence. In The Oxford Handbook of Hypnosis: Theory, Research, and Practice (Paperback, pp. 697-725). New York, NY, US: Oxford University Press.

Müller, K., Bacht, K., Prochnow, D., Schramm, S., \& Seitz, R. J. (2013). Activation of thalamus in motor imagery results from gating by hypnosis. NeuroImage, 66, 361-367.

Nash, M. R. (2012). A psychoanalytic theory of hypnosis: a clinically informed approach. In The Oxford Handbook of Hypnosis: Theory, Research, and Practice (Paperback, pp. 201-222). New York, NY, US: Oxford University Press.

Nash, M. R., \& Barnier, A. J. (2012). The Oxford Handbook of Hypnosis: Theory, Research, and Practice (Paperback). Oxford University Press.

NASW. (2008). NASW Code of Ethics. NASW. Retrieved from Peebles, M. J. (2012). Trauma-related disorders and dissociation. In The Oxford Handbook of Hypnosis: Theory, Research, and Practice (Paperback, pp. 647-679). New York, NY, US: Oxford University Press.

Raz, A., Fan, J., \& Posner, M. I. (2005). Hypnotic suggestion reduces conflict in the human brain. Proceedings of the National Academy of Sciences of the United States of America, 102(28), 9978-9983. http://doi.org/10.1073/pnas.0503064102

Saari, C. (1991). The Creation of Meaning in Clinical Social Work. New York, NY, US: Guilford Press.

Scott, E. L., Lagges, A., LaClave, L., Nash, M. R., \& Barnier, A. J. (2012). Treating children using hypnosis. In The Oxford Handbook of Hypnosis: Theory, Research, and Practice (Paperback, pp. 592-609). New York: Oxford University Press.

Scott, Sr., J. A. (1996). The Handbook of Brief Psychotherapy by Hypnoanalysis (2nd ed.). Bloomington, IN: Author House.

Siegel, M. (2006). Can we cure fear? Scientific American Mind, 16(No. 4), 44-49.

Tasso, A. F., \& Perez, N. A. (2012). Parsing everyday suggestibility: what does it tell us about hypnosis? In The Oxford Handbook of Hypnosis: Theory, Research, and Practice (Paperback, pp. 283-309). New York, NY, US: Oxford University Press.

Vanhaudenhuyse, A., Laureys, S., \& Faymonville, M.-E. (2014). Neurophysiology of hypnosis. Clinical Neurophysiology, 44, 343-353.

Vermetten, E., \& Douglas Bremner, J. (2004). Functional brain imaging and the induction of traumatic recall: a cross-correlational review between neuroimaging and hypnosis. The International Journal of Clinical And Experimental Hypnosis, 52(3), 280-312.

Watkins, J. (1992). Hypnoanalytic Techniques (Vol. II). New York, NY, US: Irvington Publishers, Inc.

Yapko, M. D. (2010). Hypnosis and depression. In Handbook of Clinical Hypnosis (2nd ed., pp. 391-413). Washington, DC: American Psychological Association. 